\title{
Empirical and Explanatory Approach of Support Effect on Newly Created Firms' Performance
}

\author{
Math Mazra ${ }^{1} \&$ Omenguele René Guy ${ }^{2}$ \\ ${ }^{1}$ Faculty of Economics and Management, Ngaoundere University, Ngaoundere, Cameroon \\ ${ }^{2}$ Faculty of Economics and Management, Dschang University, Dschang, Cameroon \\ Correspondence: Math Mazra, Faculty of Economics and Management, Ngaoundere University, P.O. Box 454, \\ Ngaoundere, Cameroon. E-mail: mathmazra@yahoo.fr
}

\author{
Received: August 6, 2012 Accepted: August 14, 2012 Online Published: August 23, 2012 \\ doi:10.5539/jms.v2n2p293 URL: http://dx.doi.org/10.5539/jms.v2n2p293
}

\begin{abstract}
The objective of this paper is to identify the different forms of entrepreneurial support and assess their impact on the performance of newly established companies in order to identify the most appropriate support forms for these companies. To achieve this goal, our research is based on a literature review on the question followed by an empirical study on 127 newly established companies to make the connection between theory and reality. Using two types of statistical tools namely fuel descriptive tools such as principal component factor analysis for the purification of scales measuring performance and support; explanatory guidance tools such as multiple linear regressions to test our research hypothesis taking into account the phenomenon of interaction between the possible dimensions mentoring, we found a positive impact of support to newly established firms on the performance. The linear regression linking the variable "support" and the variable "performance" showed that three of the four dimensions of the variable support highlighted by factor analysis (support by the network and commercial relationship, financial support by professional organizations for funding and technical and managerial support by independent experts) are all positively and significantly related to performance.
\end{abstract}

Keywords: support, mentoring, newly created firm, performance

\section{Introduction}

For over twenty years, the survival and success of start-ups concern at the same time researchers, public authorities and entrepreneurs. The fragility of these companies is widely recognized (Berger Douce, 2005), its establishment is also characterized by numerous failures (Bares, 2004), but their role in terms of contribution to the economic growth of the nation is obvious. Thus, several studies in entrepreneurship and focusing on the entrepreneur are conducted to show that the entrepreneur for his motivations and his skills is the main actor in the company creation, its development and success. Lorrain (1998), Ibrahim and Ellis (1986), Ibrahim and Goodwin (1986) showed that the entrepreneur qualifications are an important condition, if not the essential one, for the creation, survival and the success of the company.

It is certain that having entrepreneurial skills in management is an asset for leaders of newly created businesses, but given the changing business environment, these entrepreneurs will gain in acquiring new skills which match with the current business environment or in upgrading their previous ones. It is not enough for managers to just possess unique skills to be able to manage a newly created company, it is important to continually update their skills and continue making effort to individualized learning which necessarily goes through their coaching.

Indeed, coaching constitutes generally a field of interest for researchers in management and especially in entrepreneurship (Sammut, 1998a; Hernandez, 1999; Cuzin and Fayolle, 2004; Barès, 2004). It is identified as a guarantee for the survival of young firms. It contributes according to Allen and Rahman (1985) to create a favorable environment for entrepreneurship, by providing a safe environment to project, by offering a number of services and allowing entrepreneurs to be in contact with others.

An appropriate accompaniment boosts significantly the performance of the company that has just started its activities. However, support remains far from being a rule of success. The need for support expressed by newly established companies is certain but an all-out support is not the appropriate response to these needs. This is also the reason for Sammut (1998a) to talk about coaching performance. 
There exist numerous support structures, but the question in this paper is to know which appropriate kind of support is for newly established companies. In other words, what support should be sought for the newly created firm performance and survival?

\section{Literature Review}

In business, there is no need to show any more that newly established firms are the most fragile and are therefore those with higher record of bankruptcy. Even within the newly established companies, the higher bankruptcy rate concerns mostly firms established within one to four years, with the highest rate of bankruptcy for companies of two years old (Rieg, 2002). According to INSEE, the average of four out of ten companies closes before the end of the third year of their existence (Lamontagne and Thirion, 2000). Several factors are identified as determinants of performance for newly established companies including coaching that appears as an external solution to the multiple problems these companies are facing.

Indeed, the strategic method of the entrepreneur is facilitated by quality support, as shown Hernandez (1999) referring to one of his previous studies highlighting the positive role played by companies incubators in the process of economic emergence. According to the author, the ripening process during which the entrepreneurial support by external structures is essential is when to check the consistency of the creator business plan.

According to research made by the Agency for Business Creation (PACE, 1998), the approach chosen to prepare the business project will determine the survival of young firms. The results of these studies have shown that the more an entrepreneur takes advices, the more the chance of survival of the newly created firm increases. These results are confirmed by those of Dokou et al. (2000) showing that the survival of young firms would be increased by advices and financial support, commercial and strategic. This last aspect is often neglected according to Hernandez (1999) which emphasizes the lack of real strategic vision in many startups.

Moreover, Dokou et al. (2000) highlight the impact of entrepreneurial support on the survival of local startups, emphasizing the need to integrate this process into a regional dynamics, referring to Julien and Marchesnay (1996). In this logic of coaching insertion into territorial dynamics, Sammut (2003) estimated that the relevant support would be one that is rooted in the duration, synonymous to a symbiotic relationship between mentor and trainee. But for Nabli (2008), the success of the entrepreneur seems to depend primarily on its network. A study by the European Commission in 2002 reported a bankruptcy rate two to four times lower than the national average when start-ups are followed by incubators and firms (Chabaud et al., 2003).

In general, the literature seems to agree on the influence of a powerful support on the survival of newly created firms (Sammut 1998a, 1998b, 2003; Hernandez, 1999; Dokou et al., 2000, Chabaud et al., 2003; Lasch, 2004). From these analyzes, we make the assumption that relevant support has a positive influence on the performance of newly established companies.

\section{Theoretical Framework}

To better carry out the theoretical debate discussed in this paper, it is important to firstly mention an overview of the coaching concept and its foundations, then to explore the performance of the company and finally, raise the theoretical relationship between coaching and performance of newly created firms.

Based on definition given by Cuzin and Fayolle (2004: 79), coaching is presented as a practical aid to the creation of business based on a relationship developed over time and which is not punctual between an entrepreneur and an external individual to the project establishment. Through this relationship, the entrepreneur will perform multiple learning and will be able to access resources and develop useful skills for the accomplishment of his project.

Coaching is thus part of a process of individualized support between a mentor and trainee. It is characterized by the presence in the duration, a regular frequency in the relationship, relationships uniqueness, easy access to resources and establishment of contingent relationship and exchange (Cuzin and Fayolle, 2004). Thus as stated Dokou et al. (2000), coaching takes the form of a genuine rapprochement between the current and potential creators on one hand, and local institutions, on the other hand, which have the technical, human and financial resources to ensure the emergence and growth of business. However, the success of this collaboration depends on a correct diagnosis of the needs of trainee staff, the existence of appropriate mentors, with relevant mentoring practices and an absence of barriers to the use of support.

\subsection{The Needs in Support for Newly Established Firms}

It is established that the newly created companies have a special need of support (Birley and Westhead, 1992). Indeed, the support structures contribute significantly to the leadership skills development or bringing solutions 
to problems that occur spontaneously in these companies.

In general, two types of support needs are usually expressed by companies (Plane and Torres, 1998). These include needs in expertise and in strategic management. Expert mentors are essentially required for solving technical and operational problems submitted by business leaders seeking for their assistance (Plane and Torres, 1998). According to Ferrer (1997), they work to achieve a specific outcome goal. Therefore, the leader is not directly associated to the methods used to solve the problem. His contribution is limited to financially and he will be expecting for results; thus, the mentor is fully responsible for the whole operation.

However, mentors in management strategies are mostly generalist consultants, facilitators or providers of guidance with uncertain results (Ferrer, 1997). Unlike the experts who are responsible for the operation, they simply contribute by helping leaders to solve their own problems via transmitting appropriate methods and tools. They act as advisors after problems identification or the leader's needs. They are also involved in developing skills of leadership through training.

\subsection{The Various Forms of Support for Newly Established Companies}

Few researches have been conducted on the forms and methods of start-ups coaching. Moreover, the majority of literature remains limited although dedicated to large enterprises (Forestier, 2002). While, as pointed out by Albert et al. (2003), entrepreneurial support structures are becoming more numerous and this is a global phenomenon. The most known forms of coaching in entrepreneurship are: entrepreneurial coaching, mentoring and the entrepreneur personal network, etc.

\subsubsection{Entrepreneurial Coaching}

Entrepreneurial Coaching is a coaching spot to entrepreneurs whose businesses are starting up or are at early growth stage. Entrepreneurial coaching meets a specific need for acquisition, development and improvement of skills required to manage the company (Fortier, 2003). Although coaching is undeniably one of the oldest professions in the world, its proven concept as a final stage of professional and personal development is a real innovation. It's an activity that tends to develop with the emergence of an entrepreneurial society (Audretsh, 2007). In practice, it aims to create conditions for the person (or team being coached) enabling him to find and build his own solutions. It is the timely resolution, or short term sought, from the perspective of a development both sustainable and comprehensive. Therefore, entrepreneurial coaching constitutes a sufficiently personalized approach of coaching, allowing executive beginners to develop their leadership skills (Bisk, 2002; Deakins et al., 1998; Graham and O'Neill, 1997).

\subsubsection{Mentoring}

The mentor is defined as an influential and highly placed individual in the life of the mentored or in his working environment, who has significant knowledge and experience, and who is willing to provide to the mentored, an upward mobility and support for his career (Ragins and Scandura, 1993). The mentor encourages the young entrepreneur to think and encouraged him to learn from his actions in critical situations, which allows him to modify his behavior in the future or at least to learn a lesson (Bisk, 2002; Graham and O'Neill, 1997; Sullivan, 2000). In the same sense, Cope and Watts (2000) mention the role of the mentors' support in helping the mentored to engage himself in a reflective learning about events experienced in the firm in order to avoid or reduce critical periods in the future.

According to Krueger Wilson (1998), entrepreneur needs a mentor more than any other person, especially because of the complexity and variety of the tasks he has to accomplish. In the same vein, it is desirable that the leader of growing SMEs be accompanied by a mentor. Indeed, his learning would be facilitated by a mentor who would be able to transform his own knowledge and make it compatible with those of the novice entrepreneur (Morrison and Bergin-Seers, 2002). Mentoring is also very relevant in the context of personal development of small business leader (Hudson-Davies et al., 2002); the mentor can play a positive role model, inspiring the novice entrepreneur to continue seeking for excellence (Lockwood et al., 2002). Thus, mentoring is certainly an appropriate form of support for the entrepreneur, enabling him to increase his management skills and learning with the support of a person with an extensive business experience.

\subsubsection{Entrepreneur Network}

Boutillier and Uzunidis (1999) are placing the social capital at the heart of entrepreneurial dynamics. Social capital is the set of actual or potential resources which are linked to a long term network of more or less institutionalized relationships of mutual acquaintance and international recognition (Bourdieu, 1980). Boutillier and Uzunidis explain that the entrepreneur capital is organized around three dimensions: a "financial capital" consisting of financial resources and access channels, a "capital of knowledge" consists of technical know-how, 
training and learning and a "relationship capital" institutional or formal, with family, banks, other businesses, state, etc..

\section{Practices and Obstacles in Coaching Newly Established Firms}

Traditionally, support is organized according to a sequential logic consisting of three main stages: a preliminary counsel to inform and educate project leaders on the importance of good preparation for the creation, coaching ante-creation which aims to assist for the project ripening with a clarification of technical content, an awareness of strengths and weaknesses and assessment of the creator environment, and mentoring test where the incubator continues to monitor the project by more specific training and by providing support such as logistics (Lefevre and Van Haerpen, 2006).

Although coaching has proven its necessity, the use of external assistance by start-ups is not an easy task. Several barriers, mostly psychological prevent the leaders of these companies to use coaching. In fact, the real problem is that there is a fear of these companies vis-à-vis the mentors. Atamer et al. (1989) stressed that, in a society where the legend of crooks consultants has grown and has left lasting scars, looking for an initial trust is undeniably the most important brake on the development of the use of coaching. It seems that an essential process in coaching confidence is inspired by the mentor. This is a pledge of loyalty in the duration of start-ups to the mentor (Van Bunnen and Raone, 2011). Moreover, there are other psychological factors related to the fact that the owner-manager must be able to fend alone, because for some of them, asking for external advice is considered as a humiliation (Belet, 1993).

In reality, the problem lies in the perceived legitimacy of the mentor. Support structures appear somewhat legitimate, that is to say not very attractive for young business leaders; despite the potential transfer of know-how they represent (Cullière, 2003). The author argues that the legitimacy of the mentor is designed as a representation of the leaders of young companies, with a desirable mentor, appropriate or fair, compared to a system of norms, values, beliefs and definitions that exist within a range of these companies. His work resulted in a model of encouraging the use of external services management support, highlighting seven attributes of the legitimacy of the mentor: The level of expertise, Finalization, Empathy, the level of interactivity process, the level of involvement, readability or cognitive dimension of the prescriber, the reputation, that is to say, the image of room service, through the recommendations of peers or so considered trusted persons.

\section{Firm Performance}

According to Gilles (1994), the operational approach of performance is to turn the concept into a research tool, to make it able to identify realities. Performance is addressed by different units of measure, and we can find objective and subjective measures.

Objective measures are mainly in the field of accounting and finance, the securities industry and the field of strategic analysis; which allow easy comparisons between organizations. However, although objective measures provide a good comparison between companies, they are not always suitable for all types of organization. In some cases, objective measures are not adequate due to the specificity of the sector in achieving results making it difficult for all comparison, because of the multiplicity of business activities or difficulties in obtaining accounting information. Thus, for the use of objective data in the study of newly created firms, Chandler and Hanks (1993) summarize some impossibilities: Financial measures are ineffective if the company does not release its results; the specificity of Investment in young companies can skew accounting results, a single accounting measure doesn't exist to explicit the multidimensional concept of performance; the observed performance, accounting for results, is strongly linked to the type of industry; the financial measures often require long-term analysis.

In the same logic as Chandler and Hanks (1993), Eccles and Pyburn (1992) point out that even though it may seem legitimate to consider the financial data as the ultimate measure of corporate performance, yet there are significant limitations on indicators of accounting performance. They cite among others, the late nature of information, the disconnection between short-term reporting practice and long-term strategies, the capital markets informational purpose rather than decision support. Thus, perceptual criteria for measuring performance are used by some authors to address shortcomings highlighted by methods using objective criteria. Dess and Robinson (1984), Venkatraman and Ramanujam (1985), attempt to conclude that perceptual criteria do not include significant biases. These perceptual criteria nevertheless raise criticism, since they make it difficult to compare company's performance. It allows measuring the satisfaction of actors which is connected to the initial expectations and necessarily varies from one company to another. Moreover, these criteria are not interested in an overall organizational perception, being limited mostly on measuring the perception through the view of some managers. However, these criteria are relevant for measuring performance in the case of companies whose 
financial statements are confidential.

For the case of newly established companies, objective comparison of performance is quite difficult if not impossible. Given the youth of these companies, it is not obvious that all financial information was made available to the researcher. It is more accurate to use information from the managers' perception.

\section{Methodology and Model}

\subsection{Sample}

The surveyed population consists of newly established companies in Cameroon. These companies are aged 3 to 5 years, headquartered in Yaoundé, Douala, Maroua, Garoua and N'Gaoundéré. Their age was chosen as the control variable of firms' membership to the sample. A company is considered newly established when it age varies between 0 and 5 years. However, given the fact that it is not possible to study the performance of a company under the age of 3 years, we focused the surveyed population between the ages of 3 to 5 years.

For our sample, we used several databases of different Tax Services. At the General Direction of Taxes in Yaoundé, we had access to three databases, namely the file of the Directorate General of Taxes. But It seemed composed mainly of large companies and most were old or multinational companies; the files of the CIME Yaoundé and CIME Douala which include medium enterprises. They were more usable for our object of study and included all the information on both the creation date as the business location. To complement these lists that contain only new medium and large size companies, we used the Internal Revenue Divisional Centers which allowed us to have the directory of small and very small start-ups.

To gather the necessary information for our object of study, we used a questionnaire survey method. It appears as one of the most efficient ways of collecting primary data. It indeed offers the possibility for a good standardization and comparability of the measure and helps to preserve anonymity of data sources (Baumard et al., 2003). Indeed, the survey offers certain advantages, among which flexibility and versatility, speed in submission, easy intelligibility, saving time and money, possibility of statistical inference (Tardy, 1999).

Our questionnaire was submitted by ourselves and face to face during the first quarter of 2009. We initially selected a sample consisting of 250 newly established firms from our sampling frame. Unfortunately, in the field, we faced several problems including the company localization and even when some companies are localized, some owner-managers did not consider useful to focus on a questionnaire that does not provide anything to them. So after our first interview followed by several reminders in some companies, we ended up with 168 questionnaires submitted, representing $67.20 \%$ of the initial sample. After counting, 41 questionnaires were invalidated. Our sample was finally composed of 127 newly established firms (50.80\% of the initial sample), breakdown by region as follow: Yaounde (36 companies, representing $28.3 \%$ of the total sample); Douala (38 companies, representing $29.9 \%$ of the total sample); Ngaoundere (16 companies, representing $12.6 \%$ of the total sample); Garoua (19 companies, representing $15.0 \%$ of the total sample); Maroua (18 companies, representing $14.2 \%$ of the total sample).

The proportions of responses by region are related to the number of companies. Douala is the city with the most newly established firms followed by Yaounde. Ngaoundere is the least important city in terms of firm's number.

\subsection{Variables and Model}

\subsubsection{Indicators for Measuring the Performance}

The objectives of the new company and small enterprises are various in number, and integrate different analyzes (Paturel, 1997). Many authors use specific financial indicators, but these require sound knowledge of the manager (Demen Meier, 2007). Experts interviewed by Bergin-seers and Jago (2007) on the performance measurement recognize that in small firms (less than 9 employees) the most important performance indicator is the benefit.

Other authors such as Le Roy (1994) will prefer to goals, perceptual indicators such as the current profitability, the profitability trend, the evolution of sales, changes in market share and evolution of workforce. Going in the same direction as Le Roy (1994), Messeghem (1999) provides a measure of performance in terms of profitability, number of employees, turnover and product quality. In addition, a question is asked to request an assessment of profitability from high deficit to very profitable.

Cooper and Artz (1995) measured the performance of new enterprises three years after the starting date through the satisfaction of the entrepreneur on a scale of 0 to 9 points by asking him to compare his actual situation to the one he expected from the first months of startup. The comparison was made at three levels: the expected revenue, expected profits and the overall satisfaction of the entrepreneur on the current situation (each with a rating of 0,1 
and 2 for a comparison result below, equal or above). He has been also asked the question: if you had to restart your business, would you do it the same way? With a rating of 3 for "yes the same way", 2 for "yes, but not in the same way" and 0 for "not at all". After recoding the scale on entrepreneur satisfaction to make it three scales $(0,1,2)$, the summation of four notes including the his satisfaction on the three items namely expected revenue, expected profits and the overall satisfaction, and what he would do if it's to restart his business, gives a minimum score of 0 for an entrepreneur to 9 totally disappointed if he is completely satisfied.

From these works, we think that it's more accurate to measure the performance of newly established companies through the satisfaction of the entrepreneur with respect to perceptual indicators used by Le Roy (1994) and Messeghem (1999). Satisfaction is considered as a "no gap between what was expected from an action and the result obtained; while dissatisfaction is the result of a disconfirmation between the expectations of the individual and the reality it appears to him" (Saporta and Verstraete, 2006). As a result, the company would be considered as having performance when the entrepreneur has a high level of satisfaction vis-à-vis the performance indicators used and not when the entrepreneur satisfaction is low.

The performance indicators used in this paper are: the accumulated reserves, investments, profits, the level of current revenue and current profitability. Satisfaction of the entrepreneur will be assessed on a Likert-type scale with 5 points, from very dissatisfied to very satisfied. The company will be called successful when the entrepreneur has a high satisfaction score and less efficient for a low satisfaction score. The theoretical score is obtained by: [5 (theoretical minimum score) +25 (theoretical maximum score) $/ 2=15$. We will call the company successful for a score above the theoretical mean and non-successful when the score is less than or equal to this average.

\subsubsection{Measuring Support}

There are few or nonexistent researches explaining the phenomenon of mentoring firms. Most of these researches are limited to identifying different existing support structures and sometimes, not very comprehensive. In our context, the study of Nkakleu and Fouda Ongodo (2009) identified a set of practices and business support. Inspired by this research and our exploratory study, we selected as practices and newly created business support in Cameroon: research and consulting firms, commercial banks, microfinance institutions, training facilities; suppliers, family and staff; academics, leader social network (members of associations and tontines), Chamber of Commerce and Industry and the National Employment Fund. The degree of use for newly established companies of such practice will be evaluated on a Likert-type scale measuring 5-point ranging from never to regularly.

\subsection{Data Analysis}

The data were processed in SPSS. Two types of statistical tools were mobilized: fuel descriptive tools such as principal component factor analysis for the purification of scales measuring performance and mentoring; explanatory guidance tools such as multiple linear regressions to test our research hypothesis taking into account the phenomenon of interaction between the possible dimensions of support.

\subsection{Purification of Measurement Scales}

\subsubsection{Purification of Scales for Measuring the Performance}

Performance is measured in this paper by a set of five items. To measure the internal consistency of these items, we had to calculate the Cronbach's alpha. This so-called reliability analysis gave us the following results: value of Cronbach's alpha equal to 0.82 . This coefficient is very satisfactory as far above the theoretical recommended minimum. The test of the variance between the items gives us an $\mathrm{F}=10.86$ for a probability of 0.000 . The test of additivity of Turkey meanwhile gives us $\mathrm{F}=0.093$ for a probability of 0.760 . These results allow us to accept the hypothesis of additivity of our items.

After performing a factor analysis to assess the overall adequacy of our data, the result gives a value of KMO = 0.881 . This value is good and thus proves a good fit between our observations and processing techniques. This match is confirmed by the Bartlett test with a value of 452.703 with a significance level of 0.000 . This implies that the correlation matrix of the items cannot be considered unitary. The table 1 presents the ACP result. The result shows that performance is one-dimensional and all items are well correlated to that single axis which explains $74.82 \%$ of the total variance in our sample. In addition, all items are adequately addressed by this single axis as the commonalities that measure the proportion of the variance of the variable explained by the factors identified by factor analysis are all greater than 0.64 . Similarly, the correlation coefficients of the items are all above 0.80 .

We conclude on the basis of these results that the variable performance of newly established companies (PENC) is one dimensional. 
Table 1. Factor analysis on performance item (without rotation)

\begin{tabular}{lll}
\hline Items & F1 & communalities \\
\hline Accumulated reserves & 0.841 & 0.708 \\
Investments & 0.803 & 0.644 \\
The profits & 0.814 & 0.835 \\
Current turnover & 0.835 & 0.698 \\
Current profitability & 0.826 & 0.857 \\
Eigen values & 3.741 & \\
\% explained variance & 74.823 & \\
Cronbach's Alpha & 0.82 & \\
\hline
\end{tabular}

\subsubsection{Purification of the Mentoring Measurement Scales}

Mentoring is measured in this paper by a set of 10 items. These items are adapted from the work of Nkakleu and Fouda Ongodo (2009). The reliability analysis gave us the following results: a value of Cronbach's alpha equal to 0.75 which is very satisfactory as far above the theoretical minimum of 0.60 . The variance test between the items gives us an $\mathrm{F}=37.33$ for a probability $\mathrm{P}$ of 0.000 . The non-additivity test of Turkey gives for $\mathrm{F}=0.86$, a probability $\mathrm{p}=0.43$.

To complete our analysis, a suitability test of the ACP related to the data was made and thus the results give us a $\mathrm{KMO}$ value equal to 0.66 . This value is very good and thus proves a good fit between our observations and the adopted processing techniques. This satisfactory result is further confirmed by Bartlett test with a value of 625.175 with a significance level of 0.000 . These results reflect the fact that the correlation matrix of items has a suitable structure for the ACP and the results are presented in the table 2.

Table 2. Factor analysis on mentoring items (after rotation)

\begin{tabular}{lccccc}
\hline Items & F1 & F2 & F3 & F4 & Communalities \\
\hline Partners & 0.925 & & & & 0.813 \\
The family environment and staff & 0.875 & & & & 0.896 \\
Association members and tontine & 0.867 & & & & 0.910 \\
Academics & & 0.783 & & & 0.850 \\
Chamber of Commerce and Industry & & 0.864 & & & 0.880 \\
The National Fund of Employment & & 0.833 & & & 0.846 \\
Commercial banks & & & 0.819 & & 0.627 \\
Microfinance institutions & & & 0.830 & & 0.813 \\
The research and consultancy firm & & & & 0.855 & 0.751 \\
Training structures & 3.519 & 2.068 & 1.342 & 0.904 & 0.700 \\
Eigen values & 35.195 & 55.873 & 69.289 & 80.859 & \\
\% Variance explained & & & \multicolumn{2}{c}{0.752} & \\
Cronbach's alpha & & & &
\end{tabular}

It appears from that table 2 that, the variable support of our study has four relevant dimensions, and all items of the first four factors have a correlation greater than 0.62. As shown in the table 2, the first factorial axes are correlated each with three items that all have correlation coefficients above 0.80 . The other two factor axes are each correlated with two items. The 10 items have communalities above 0.60 and approaching unity as advocated by the Kaiser criterion.

In compliance with this criterion, four factors highlighted explained $80.86 \%$ of the total variance in our sample. The first factor is one that is strongly correlated to the first three items namely: partners, family and staff and members of associations and tontines. The first axis can be called "the support network and business relationship" (ARRC). The second factor is also strongly correlated with the three following items: the university, the Chamber of Commerce and Industry and the National Employment Fund. We call this axis "support by dedicated professional organizations" (ASPD). The third factor is in turn strongly correlated with two items: Commercial banks and microfinance institutions. We named this axis "Financial support by professional financing structures" (AFSPF). The fourth factor axis is also correlated with two items: The research and consultancy firm and training structures. We call it "technical and managerial support by independent experts" 


\section{(ATMEI).}

The question is which of these types of support is appropriate for newly created enterprises. The linear regression model linking these dimensions of support and performance is presented as follow:

$$
P E N C=a+b_{1}(A R R C)+b_{2}(A S P D)+b_{3}(A F S P F)+b_{4}(A T M E I)
$$

\section{Results}

Analysis of frequencies showed that the newly created firms in Cameroon are heterogeneous. They are of various sizes and all activity sectors. Their creation modes are also diverse. However, more than $87 \%$ of these companies were mounted and put in place by the sponsors their selves against $13 \%$ in which $9 \%$ purchase and $4 \%$ by inheritance. Concerning their size, our results following the FOGAPE classification show that $70.9 \%$ of newly created businesses are composed of very small enterprises; $26.8 \%$ of small enterprises; $2.4 \%$ of medium enterprises and $0 \%$ of the big ones. These results appeared normal, because it would be deadly for an under 6 years old company to have 200 and more staff members.

Moreover, most of the companies are individual enterprises (67.7\%), followed by limited liability companies (11.8\%), limited companies (7.1\%) and general partnership companies $(3.9 \%)$ then by one-person limited companies $(0.8 \%)$. Sixteen activity sectors were listed, including information and communication technologies sector, which is the most representative (more than a quarter of the total).

We proceeded with linear regression analysis between the mentoring dimensions identified above and performance (table 3). The results gave a correlation coefficient $R$ of 0.682 and a determining coefficient $\mathrm{R}^{2}$ of 0.465. In addition, the Fisher test gives an $\mathrm{F}$ value equal to 26.545 for 4 and 122 degree of freedom with a significance probability of $p=0.000$. These results show that the overall fit of the model is very satisfactory. Regarding the Student's test, the results highlight that three of the four dimensions of support are significantly related to performance. This is the support by the network and business relationship, the financial support by the professional structures of funding and technical and managerial support by independent experts (all at 0.000 ). The dimension support by professional organizations is not significantly related to performance of the newly created company.

Table 3. Summary results of the regression between mentoring and performance

\begin{tabular}{lllllll}
\hline Results of the model & \multicolumn{5}{l}{ Regression coefficients } \\
\cline { 3 - 7 } & & Variables & ARRC & ASPD & AFSPF & ATMEI \\
\hline F Value & 26.545 & Beta & 0.434 & -0.081 & 0.395 & 0.338 \\
Signification & 0.000 & t-student & 6.558 & -1.227 & 5.967 & 5.106 \\
R & 0.682 & Significance & 0.000 & 0.222 & 0.000 & 0.000 \\
R-square & 0.465 & & & & & \\
Adjusted R-square & 0.448 & & & & & \\
\hline
\end{tabular}

\section{Conclusion}

In this paper, our results suggest the importance of using support structures to ensure the survival of the newly created company. In fact, the strong relationship found between the above mentioned dimensions and performance corroborates the studies of Dokou (2000) showing that relaying on advice and support, both financial, commercial and strategic greatly increases the survival of the newly created company. Nabli (2008) also highlight that successful entrepreneur running the newly created company would largely depend on support from its network of relationship.

For the case of support by professional structures which is not significantly related to performance, this could be explained by the timely intervention of structures dedicated to supporting and assisting companies in creation. These results are consistent with Sammut (1998a) who stresses the relevance of coaching for it to be beneficial to young companies. According to the author, mentoring is relevant when it's linked to time.

Thus, we can conclude that to perform well, the newly created company will use the support structures such as research firms for managerial or technical support; bank financing is also an important form of support since, being anchored over time and after the bank loan contracts, it obliges the company to perform good management. The commercial and relational network is also a form of support which is similar to mentoring but with the advantage of being for a long time. 


\section{References}

Allen, D. N., \& Rahman, S. (1985). Small Business Incubators: A Positive Environment for Entrepreneurship. Journal of small Business Management, 23(3), 12-22.

APCE. (1998). Créer une entreprise : l'idée, la préparation, le lancement. Édition APCE.

Atamer, T., Durand, P., Riot, P., Engel, F., \& Fixari, D. (1989). L'état, les PME et les consultants. Deuxième épisode: le marché de la confiance, Gérer Et Comprendre, Annales Des Mines, Juin.

Audretsch, D. B. (2007). The entrepreneurial Society. New York: Oxford University Press. http://dx.doi.org/10.1093/acprof:oso/9780195183504.001.0001

Barès, F. (2004). Que dire de l'accompagnement en phase de démarrage ? La perception de cinq créateurs d'entreprises technologiques à fort potentiel de croissance. Actes du 3ème congrès de l'Académie de l'Entrepreneuriat, Lyon, mars.

Baumard, P., Donada, C., Ibert, J., \& Xuereb, J-M. (2003). La collecte des données et la gestion de leurs sources. In THIETART R-A et Coll. Méthodes de recherche en management (pp. 224-256, 2nd ed.). dunod, Paris, France.

Belet, D. (1993). Prestations de conseil auprès des PME-PMI et processus d'apprentissage de leurs dirigeants: pour une autre conception du métier de conseil en management. Revue Internationale PME, 6(2), 108-134.

Berger-Douce, S. (2005). L'accompagnement entrepreneurial par un incubateur universitaire - le point de vue critique d'un créateur. IVème Congrès de l'Académie de l'Entrepreneuriat. Retrieved from http://www.entrepreneuriat.com/fileadmin/ressources/actes05/Berger Douce.pdf

Bergin-Seers S., \& Jago, L. K. (2007). Performance Measurement in Small Motels in Australia. Tourism and hospitality Research, 7(2), 144-155. http://dx.doi.org/10.1057/palgrave.thr.6050036

Birley, S., \& Westhead, P. (1992). A Comparison of New Firms in "Assisted" and "Non Assisted" Areas in Great $\begin{array}{llll}\text { Britain. Entrepreneurship and Regional Development, 4(4), 299-338. } & \text { and }\end{array}$ http://dx.doi.org/10.1080/08985629200000018

Bisk, L. (2002). Formal Entrepreneurial Mentoring: the Efficacy of Third Party Managed Programs. Career Development International, 7(5), 262-270. http://dx.doi.org/10.1108/13620430210440082

Bluedorn, A. C. (1980). Cutting the Gordian Knot: a Critique of the Effectiveness Tradition in Organizational Research. Sociology and Social Research, 64(4), 477-496.

Bourdieu, P. (1980). Le capital social. Actes de la Recherche en Sciences Sociales, 31. Retrieved from

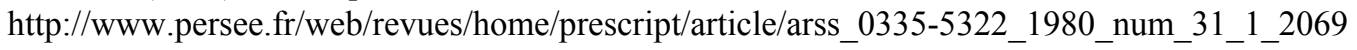

Bourguignon, A. (1995). Peut-on définir la performance. Revue Française de Comptabilité, 269, 61-66.

Bourguignon, A. (1996). Définir la performance: une simple question de vocabulaire. In Fericelli, A.-M., \& Sire, B. (Dirs.), Performances et ressources humaines (pp. 18-31). Economica, Paris.

Boutillier, S., \& Uzunidis, D. (1999). La légende de l'entrepreneur. Syros, Paris, 151.

Caby, J., Clerc-Girard, M. F., \& Koehl, J. (1996). Le processus de création de valeur. Revue Française de Gestion, mars-mai, 49-56.

Chabaud, D., Ehlinger, S., \& Perret, V. (2003). Les incubateurs d'entreprises innovantes: un réseau entrepreneurial reconfiguré. Actes de la XIIème conférence de l'AIMS, Les Côtes de Carthage, juin.

Chandler, G. N., \& Hanks, S. H. (1993). Measuring the Performance of Emerging Business: a Validation Study. Journal of Business Venturing, 8(5), 391-408. http://dx.doi.org/10.1016/0883-9026(93)90021-V

Cooper, A. C., \& Artz, K. W. (1995). Determinants of Satisfaction for Entrepreneurs. Journal of Business Venturing, 10(6), 439-457. http://dx.doi.org/10.1016/0883-9026(95)00083-K

Cope, J., \& Watts, G. (2000). Learning by Doing - An Exploration of Experience, Critical Incidents and Reflection in Entrepreneurial Learning. International Journal of Entrepreneurial Behaviour \& Research, 6(3), 104-124. http://dx.doi.org/10.1108/13552550010346208

Culliere, O. (2003). La légitimité d'accompagnateur des organismes institutionnels de conseil en management $\begin{array}{llll}\text { auprès } & \text { des } & \text { TPE. } & \text { Retrieved }\end{array}$ http://www.strategie-aims.com/events/conferences/11-xiieme-conference-de-l-aims/communications/819-la 
-legitimite-d-accompagnateur-des-organismes-institutionnels-de-conseil-en-management-aupres-des-tpe/do wnload

Cuzin, R., \& Fayolle A. (2004). Les dimensions structurantes de l'accompagnement en création d'entreprises. Communication $3^{\text {ème }}$ Congrès de l'Académie de l'Entrepreneuriat, Lyon, mars.

Deakins, D., Graham, L., Sullivan, R., \& Whittam, G. (1998). New Venture Support: an Analysis of Mentoring Support for New and Early Stage Entrepreneurs. Journal of Small Business and Enterprise Development, 5(2), 151-161. http://dx.doi.org/10.1108/EUM0000000006763

Demen Meier, C. (2007). Les TPE d'un secteur en difficulté, stratégies et performance: la restauration de l'Arc Lémanique Suisse. Thèse de Doctorat en Sciences de Gestion, Université de Caen, France.

Dess, D. D., \& Robinson Jr., R. B. (1984). Measuring Organizational Performance in the Absence of Objective Measure: the Case of the Privately-held Firm and Conglomerate Business Unit. Strategic management journal, 5(3), 265-273. http://dx.doi.org/10.1002/smj.4250050306

Dokou, G. A., Baudoux, M., \& Roge, M. (2000). L'accompagnement managérial et industriel de la PME. L'harmattan, Paris.

Eccles, R. G., \& Pyburn, P. J. (1992). Creating a Comprehensive System to Measure Performance. Management accounting, October , 41-44.

Ferrer, M. I. (1997). L'évaluation des prestations de conseil en management stratégique: de la performance à la cohérence. VIe Conférence de l'Association Internationale de Management Stratégique (AIMS), 25 au 27 juin, Montréal (Canada).

Forestier, G. (2002). Regard croisés sur le coaching. Editions d'Organisation.

Fortier, G. (2003). Mentor ou coach? Voilà la question! Retrieved from http://www.portail-rhri.com/votre_emploi/article.asp?idFicDoc $=12552$

Gauzente, C. (2000). Mesurer la performance des entreprises en l'absence d'indicateurs objectifs: quelle validité ? Analyse de la pertinence de certains indicateurs. Finance Contrôle Stratégie, 3(2), 145 - 165.

Georgopoulos, B. S., \& Tannenbaum, A. S. (1957). A Study of Organizational Effectiveness. American Sociological Review, 22(5), 534-540. http://dx.doi.org/10.2307/2089477

Graham, L., \& O'neil, E. (1997). Sherpa or Shepherd: The Adviser Relationship in Small Firms -Mentor and/ or Consultant? Paper presented at the 20th ISBA National Conference.

Hall, R. H. (1980). Effectiveness Theory and Organizational Effectiveness. The Journal of Applied Behavioral Science, 16, 536-545. http://dx.doi.org/10.1177/002188638001600408

Hernandez, E. M. (1999). Le processus entrepreneurial: Vers un modèle stratégique d'entrepreneuriat. L'Harmattan, Paris.

Hudson-Davies, R., Parker C., \& Byrom, J. (2002). Towards a Healthy High Street: Developing Mentoring Schemes for Smaller Retailers. Industrial and Commercial Training, 34(7), 248-255. http://dx.doi.org/10.1108/00197850210447237

Ibrahim, A. B., \& Ellis, W. (1986). An Empirical Investigation of Causes of Failure in Small Business and Strategies to Reduce It. Journal of Small Business and Entrepreneurship, 4(3), 44-52.

Ibrahim, A. B., \& Goodwin, J. R. (1986). Perceived Causes of Success in Small Business. American Journal of Small Business, 11(2), 41-50.

Kalika, M. (1988). Structures d'entreprises: réalités, déterminants et performances. Economica, Paris.

Krueger Wilson, C. (1998). Mentoring the Entrepreneur. Nursing Administration Quarterly, 22(2), 1-12.

Lamontagne, E., \& Thirion, B. (2000). Création d'entreprise: les facteurs de survie. INSEE Première, 703.

Lasch, F. (2004). Pérenniser les jeunes entreprises : constats, outils et démarches. Table-ronde organisée lors du $7^{\text {ème }}$ CIFEPME, Montpellier, octobre.

Le Roy, F. (1994). Doctrines Militaires et Management Stratégique des Entreprises. Thèse de Doctorat en Sciences de Gestion, Université Montpellier I, France.

Lefèvre, M., \& Van Haeperen, B. (2006). Evaluation des couveuses d'entreprises, des coopératives d'activités et des incubateurs en économie sociale en Région wallone. Institut Wallon de l'Evaluation et de la Prospective 
et de la Statistique (IWEPS), Discussion Papers, $\mathrm{n}$ 0602. Retrieved from http://www.iweps.be/sites/default/files/dp0602.pdf

Lenz, R. T. (1981). Determinants of Organizational Performance: an Interdisciplinary Review. Strategic Management Journal, 2(2), 131-154. http://dx.doi.org/10.1002/smj.4250020204

Lockwood, P., Jordan C. H., \& Kunda Z. (2002). Motivation by positive or negative role models: Regulatory focus determines who will best inspire us. Journal of Personality and Social Psychology, 83(4), 854-864. http://dx.doi.org/10.1037/0022-3514.83.4.854

Marchesnay, M., \& Julien, P. A. (1996). L'entrepreneuriat, Economica, Gestion poche, Paris, 111.

Martory, B., \& Crozet, D. (1993). Mathematics and organization theory. In March, J. G. (Ed.), Handbook of Organizations (pp. 335-386). Rand McNally.

Messeghem, K. (1999). Contribution à la Compréhension de l'Adoption d'un Modèle d'Assurance Qualité en $P M E$ : le Cas des Industries Agro-Alimentaires. Thèse de Doctorat en sciences de gestion, Université Montpellier I, France.

Morin, E. M., Savoie, A., \& Beaudin, G. (1994). L'efficacité De l'organisation. Théories, représentations et mesures. Gaëtan Morin, Montréal, 158.

Morrison, A., \& Bergin-Seers, S. (2002). Pro-growth Small Businesses: Learning "Architecture". Journal of Management Development, 21(5), 388-400. http://dx.doi.org/10.1108/02621710210426871

Nabli, R. (2008). Les entrepreneurs tunisiens. La difficile émergence d'un nouvel acteur. L'Harmattan, Paris, 444.

Nkakleu, R., \& Fouda Ongodo, M. (2009). Influence des structures d'accompagnement sur les pratiques de gestion de 250 PME/ PE camerounaises en phase de démarrage. Retrieved from www.entrepreneuriat.auf.org/IMG/pdf/A5C13_FINAL.pdf

Paturel, R. (1997). Pratique du management stratégique. Collection la Gestion en Plus, Presses Universitaires de Grenoble (PUG), Grenoble, France, 150.

Quinn, R. E., \& Rohrbaugh, J. (1981). A Competing Values Approach to Organizational Effectiveness. Public Productivity Review, 5(2), 122-140. http://dx.doi.org/10.2307/3380029

Rieg, C. (2002). Les défaillances d'entreprises. INSEE Première, $\mathrm{n}$ 866. Retrieved from $\mathrm{http}: / /$ www.insee.fr/fr/ffc/docs_ffc/ip866.pdf

Sammut, S. (1998a). Jeune entreprise - la phase cruciale du démarrage. L'Harmattan, Paris.

Sammut, S. (1998b). Comment aider les petites entreprises jeunes? Revue française de gestion, novembre-décembre, 28-41.

Sammut, S. (2003). L'accompagnement des petites entreprises en création. In Marion, S., Noel, X., Sammut S., \& Senicourt, P. (Eds.), Réflexion sur les outils et les méthodes à l'usage du créateur d'entreprise. les éditions de l'ADREG. Retrieved from http://www.adreg.net

Scandura, T. A., \& Ragins, B. R. (1993). The Effects of Sex and Gender Role Orientation on Mentorship in Male-Dominated Occupations. Journal of Vocational Behavior, 43(3), 251-265. http://dx.doi.org/10.1006/jvbe.1993.1046,

Sullivan, R. (2000). Entrepreneurial Learning and Mentoring. International Journal of Entrepreneurial Behaviour \& Research, 6(3), 160-175. http://dx.doi.org/10.1108/13552550010346587

TARDY, E. (1999). Différence de genre et méthodologie: importance de jumeler le "quantitatif" au "qualitatif". Recherches qualitatives, 19, 93-108.

Torres, O., \& Plane, J. M. (2003). Le recours au conseil est-il dénaturant pour les PME ? La Revue du Financier, $140,38-46$.

Van Bunnen, G., \& Raone, J. (2011). L'auto-création d'emploi en couveuses d'entreprises en Wallonie : Entre pratiques d'accompagnement et dynamiques institutionnelles. Louvain School of Management. http://www.uclouvain.be/cps/ucl/doc/iag/documents/WP_2011_13_Van_Bunnen_Raone.pdf

Venkatraman, N., \& Ramanujam, V. (1986). Measurement of Business Performance in Strategy Research: a Comparison of Approaches. Academy of Management Review, 11(4), 801-814. http://dx.doi.org/10.5465/AMR.1986.4283976 
Verstraete, T., \& Saporta, B. (2006). Création d'entreprise et entrepreneuriat. Les éditions de l'ADREG. Retrieved from http://www.editions-adreg.net 